\title{
Bose: A Tryst with Press and Politics
}

\author{
Pritha Dutta ${ }^{1}$ \& Rajdeep Roy ${ }^{2}$ \\ ${ }^{1}$ Ph.D Scholar, Amity University, School of Communication, Uttar Pradesh \\ prithachakraborty712@gmail.com, ORCID: oooo-0oo2-3994-2084 \\ ${ }^{2}$ Asst. Professor Amity University, rroy@amity.edu, ORCID: oooo-ooo1-5316-308X
}

First published September 30, 2019

\begin{abstract}
The study examines the role of the press as a catalyst in the dominant portrayal of Subhas Bose as the political actor who has been arguably denied his rightful place in the annals of Indian history. The paper investigates the time plane in discourse analysis, the discursive strategies of social actors, and the extra- and supra-textual effects of mediated discourse (Carvalho, 2008) to advocate that press content on Bose is "shaped, pounded, constrained and encouraged by a multitude of forces" (Shoemaker, Reese, 1996). The paper critiques the discourse of The Statesman and Times of India in the light of the socio-political context and the published articles in 2015. This year was instrumental in marking a historical announcement that fundamentally influenced a seventy-year-long dialogue. The paper analyses the re-aligning of the nation's narrative to create a public consensus incidental to the particular political dispensation of the day. It examines the positioning of Bose as an alternative to the dominant narrative of the national movement with Gandhi and Nehru as central protagonists.
\end{abstract}

Keywords: Bose, Press, Politics, Critical Discourse Analysis, The Statesman, Times of India

"To remember and 'use' Subhas Bose for present purposes, it was necessary to simplify and amplify aspects of his life into familiar cultural molds"- Leonard A. Gordon(1990)

\section{Introduction}

Parallelisms, hyperboles, tri-colons, synecdoche, rhetorical questions, and anaphora dominated the newspaper pages of April 2015 as the enigma of Subhas Chandra Bose got renewed focus with the news of declassification of the Bose files bringing the spotlight back on the life of a persona shrouded in mystery. Barely a month later, Mamata Banerjee, the Chief Minister of West Bengal announced, "people deserve to know about his last days" and declassified the files kept by the State Government. In October, Prime Minister Narendra Modi, met with Bose's family. Within three months, on Bose's birth anniversary, files classified for the last 70 years were in the public domain, kept in National Archives of India and a dedicated online portal'.

Bose has been a bone of contention in press discourse since 1939, especially after he became the President of the Indian National Congress (INC) for a second time triumphing over Gandhi's candidate Dr. Pattabhi Sitaramaya. However, 2015 was unprecedented on a number of counts. It had the most number of press articles on Bose since $1939^{2}$ and number of noble Page 1

(C) AesthetixMS 2019. This Open Access article is published under a Creative Commons Attribution Non-Commercial 4.0 International License (http://creativecommons.org/licenses/by-nc/4.o/), which permits non-commercial re-use, distribution, and reproduction in any medium, provided the original work is properly cited. For citation use the DOI. For commercial re-use, please contact editor@rupkatha.com. 
placements in the English Language dailies. The year challenged "established discursive positions" and qualifies as "the peak period of coverage" (Carvalho, 2005, 2008).

This paper argues that the role of the press has remained under-explored in spite of its significant, often pivotal contribution in generating the public discourse surrounding Bose. Scholarly work on Bose(Gordon, 1990, Chakraborty, 1990, Bharadwaj, 1994, Mookherjee, Jog et al 1973, Edwardes 1963) is limited to themes such as "his early revolutionary days", "his alienation with the British rule", "the journey to Germany \& secret pact with Hitler", "his move to Southeast Asia" and "raising INA to liberate India from British Rule" (Mani, Ramasamy, 2006). The paper examines the politics of the press in portraying Bose, producing a narrative intertwined with the political dispensation of the day.

\section{Prelude}

Leonard A. Gordon (1990) notes that the newspaper, The Statesman represented the "imperial press of the country"; the English daily has "never been a friend of Bose" and had categorized him as a "Nazi" (p.437). Gordon also looks into the role of the Calcutta based newspaper Catholic Herald, which was instrumental in labeling him the brain behind the revolutionary conspiracy leading to similar stories being published in important dailies such as the Englishman and The Statesman (p.125).

In the report on the Revolutionary Press Propaganda in Bengal, prepared by the Home Department in 1924 regarding the connection between the revolutionaries and the Swarajya Party in Bengal, Bose was described as a "prominent Congress communist agitator who expressed seditious and bloodthirsty feelings" (p.116). Similarly, Nanda Mookerjee (1981) observes that the treatment of Statesman 3 and Englishman towards Bose denigrated his image (p.15). Mookerjee also examines British newspapers namely Daily Herald, Evening Standard, Evening News, The Manchester Guardian, News Chronicle, The New Statesman and Nation between 1933-1935 and concludes that Bose was framed as a "notorious extremist" and "Congress Leader in place of Nehru” (p.1-3). On February 8, 1946, approximately six months after his alleged disappearance, New York Times reported, "Indian nationalists are working day and night to build Bose as the 'George Washington' of India” (Bose, 2013, p.1). Though the press has played an active role in infiltrating public inquiry and introspection on Bose's alleged death (Jain, 1946), it has never been significantly explored in academic literature.

Press plays a seminal role in facilitating public opinion. Journalistic practices are influenced by myriad factors where dominant ideology has invariably dictated press content (Philo et al, 2013, Reese, 2007, Shoemaker, 1994). In this context, Critical Discourse Analysis (CDA) can be employed as a methodological tool "to reveal the discursive sources of power, dominance, inequality, and bias" (Dijk, 1988). The paper borrows from Anabela Carvalho's (2005, 2008) framework of Critical Discourse Analysis. The approach has been adopted as it enunciates "time-sensitive discourse analysis" and takes into deliberation the "role of actors in media discourse" and "their discursive strategies in construction of reality" (Carvalho, 2005). Carvalho's approach to CDA has been employed to study Bose, who has been sustained, produced and legitimized over seven decades by the press and political forces of the time.

The present study examines the re-presentation of Bose in the context of the language in newspaper Headline and Lead. Rotimi Taiwo (2007) observed that "ideology plays a vital role in the construction of newspaper headline", it can "initiate, sustain and shape discourse" (p.243). Lead succeeds as the "most important paragraph of the story" (Dijk, 1988). The newspapers 
selected for the exploration are the Times of India and The Statesman. Dating back to the early 180os, they are two of the longest surviving English dailies, and "great success stories..." (Hirschmann, 2004). Carvalho(2005) argues that "texts always build on previous ones, taking up or challenging former discourses" (p.18). History has an indelible impact on discourse. Both these newspapers are deeply rooted in their historical origin, hence found suitable for analysis.

\section{Framework for Analysis (Carvalho, 2005,2008)}

The analysis is categorically contextualized to first examine the "unit of analysis" and then "its wider context". The framework allows "Textual Analysis" which is examining the "dimensions of the text that matters the most in the construction of meaning" (2008, p. 167) and "Contextual Analysis", the second stage, that moves beyond the text and enquires on the "overall coverage of an event or issue in one news outlet and examine the wider social context" (2008, p. 171).

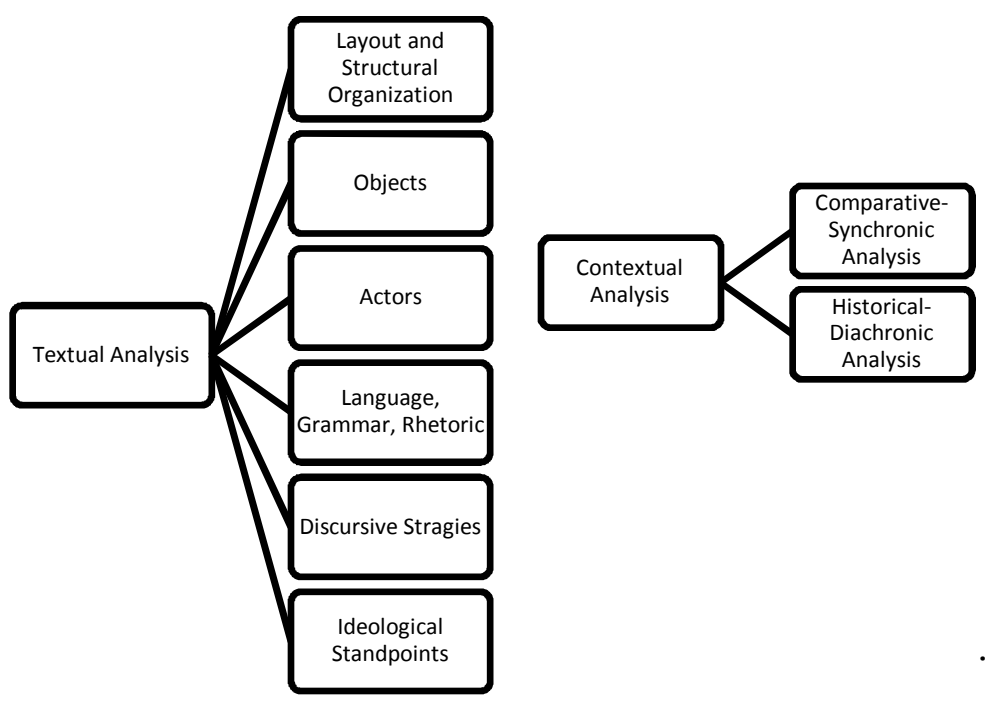

Fig. 1 Framework of Anabela Carvalho's Critical Discourse Analysis

Article 1: Times of India (Pg 1)

Modi tells Netaji kin: Will look into declassifying files

'No Other PM Agreed To Meet Family Members'

Subhro Niyogi

Kolkata: PM Narendra Modi met Netaji Subhas Chandra Bose's grandnephew Surya Bose in Berlin and promised to examine the request for declassification of all files related to events since his death or disappearance in Taiwan on August 18, 1945. (15/04/2015)

Article 2: Times of India (Pg 13)

'Must not avoid truth even if it hits Netaji's image' 
The meeting late on Monday between Modi and Surya lasted for over half-an-hour and is significant in the light of recent disclosures of Nehru administration's surveillance on Netaji's kin. (15/04/2015)

\section{Textual Analysis}

Layout and Structural Organization: Carvalho (2008) has enunciated that the examination of the optic elements of a newspaper article such as section in which the article was published, page number, size, tone of the headline and lead, can help examine the valuation and categorization given to the issue by the publication.

The article under study was published on 15.04.2015 in Times of India and authored by Shubhro Niyogi. It appeared on page 1 and was given three columns to the right top of the page. It also has a 'strap line'4 or a reverse shoulder, the purpose of which being to amplify another important point of the news, and is placed right below the headline. The news article was given very prominent and strategic placement. This article has a 'jump', to Page 13, which is given five of eight columns. The lead and the headline highlight the Prime Minister's promise to Bose's relative to declassify files related to Bose post 1945, it also fetes Narendra Modi as the first Prime Minister to have met Bose's family. The article highlights it as being a major political move at a time when Nehru's surveillance on Bose's family became a matter of public knowledge.

Objects: An analysis which is closely related to the idea of "topics or themes", the only difference is that the word, 'objects',"constitutes" rather than just refers to the realities at stake" (Carvalho, 2008. p. 167).

The main theme or object of the article is Modi's assurance to Surya Bose, grandnephew of Subhas Chandra Bose to declassify Bose files. Another important object is PM Modi's initiatives to meet and commit time in a meeting with Surya Bose in Germany. The marginal object is the event that leads to these domino effects was a revelation that Nehru's government kept a watchful eye on Bose's relatives.

Actor: Examining of individuals "referred to" or "quoted" in the article, as they play a role in "shaping the overall meaning of the text" (Carvalho, 2008, p. 168). The actors represented in the Times of India article are Prime Minister, Narendra Modi, Netaji, Netaji kin; Surya Bose, other PMs, family members and Nehru.

The majority of the presented persons are political actors, an indicator that the article's main framing is along the political lines. There is a repetition of references to Bose's relatives framing them as family members, grandnephew, and kin, consequently personalizing the issue.

The article depicts Narendra Modi as a trailblazer who has dared to do what other Prime Ministers have never done in the history of India, which is to meet Bose's family. A positive tone has been used to frame Narendra Modi, he is shown to usher hope by not just a meeting, which the author frames as "significant" but also giving it substantial time, the author mentions in the lead of the article that "over half an hour" was given to Bose's grandnephew.

The Prime Minister dominates the text. The author has used his quotation as the headline for both the stories published on the same day thus making him the prime definer of the represented reality. Subsequently, the framing of both Bose and Nehru are more questionable and 
sketchy. The author leaves doubt in the headline of the article that declassification could dampen the image of Bose whilst projecting Nehru's actions as erroneous.

Language and rhetoric- This stage entails examination of the words used for the formulation of a text and the syntax can reveal "underlying ideological presuppositions" (Carvalho, 2008, p. 168).

The language construction creates a positive political climate, wherein the Prime Minister is projected reviving an old dialogue, opening an apparently 'cold case' with a potential declassification of Bose's files. The headline strongly promotes good intentions and champions Prime Minister Narendra Modi. It can be noted that Modi had only met one person in Bose's family, one of his grandnephews. Interestingly the author uses collective nouns to represent him with words such as "kin", "family members "to conceal the lacuna of a wider representation that may have instilled the intended gravitas. One can find a resonance to presenting a singular voice as a collective response in the use of words such as "all files", "for over half an hour", "disclosures". The author appeals to a set of moral claims with headlines announcing, "No other PM...", and moralistic innuendo such as "must not avoid truth...". The author is inconsistent regarding the true intent of the government. While the headline states that the PM "will look into declassifying", the lead leaves a convenient loose end for the PM as it reads that the "request" for declassification will be "examined" by him. The author also keeps unclear whether a more private or public disclosure, if at all, can be expected.

Discursive Strategies: The framing, positioning, legitimation, politicization of press discourse constructed by social actors including journalists is explored at this juncture; it is a form of "discursive manipulation of reality" (Carvalho, 2008, p. 169).

Times of India's representation of the meeting is a powerful legitimization of Modi's intention and of the deep-rooted politics behind keeping the mystery of Bose alive. The positioning of Modi, as hope and sympathizer of Bose and his family, aids to the construction of an honest leadership while also appropriating Bose in the ideological rubric of its political position. Subhro Niyogi's use of the word "administration" instead of "government" critically amplifies Nehru as direct subject of the actions taken.

The headline in the second article published on the same day on Pg. 13 is in quotations but doesn't read if it was by Modi or Surya. It insinuates a probability that the declassification could hurt Bose's image. Subhro Niyogi's receptivity to the issue is imbalanced; he reinforces and reminds the audience of Nehru's surveillance on Bose's family. However, the author doesn't corroborate in the lead of the article on the documents that prove Nehru's surveillance on Bose's family.

Ideological standpoint- this reading is "the most fundamental shaping influence of a text" (Carvalho, 2008, p. 170).

Ideologically, this article is clearly advocating PM Modi's government, as his perspective dominates both in the headline and the lead. A strong nationalistic ideology seems to prevail in the article, as justice would finally be served to the freedom fighter overlooked by previous governments.

The idea that efforts have been made by the Prime Minister of the country to meet Bose's relative and explicitly promise to inspect files that will put to rest a 70 -year long debate reinforces administrative rationalism. The author ignores the government's strategy to meet Bose's relatives 
at an opportune time when the public discourse on Nehru's surveillance is at its peak, and the government only stands to gain political dividends from the event.

\section{Contextual Analysis}

Comparative-synchronic: It is the analysis entailing a close inspection of "various representations of an issue at the time of the writing of one specific news text in the same outlet and in others" (Carvalho, 2008, p. 171).

On $15^{\text {th }}$ April 2015,Times of India carried the story; The Statesman did not publish any article on Bose on the day. Given that the meeting of the Prime Minister with Surya Bose is an important event, the silence maintained by The Statesman promotes its ideological affiliation, as "silence can be as performative as discourse" (Carvalho, 2008, p. 171).

Times of India by publishing it on Pg 1 and then again on Pg 13 projects coherence with the government, while The Statesman's silence regarding the issue in its pages leads to a deficiency of an alternative in the discursive construction of reality.

Historical-diachronic analysis: An accounting of "historical conditions and the context of production of mediated texts" (Carvalho, 2008, p. 172).

An in-depth study of the press discourse of the said year facilitates a better understanding of the discourse surrounding Bose's political legacy. On 11.04.2015, Times of India published two stories across Page 1 and Page 12 of the newspaper. The first-page headline read "Nehru 'snooping' on Netaji kin gives BJP anti-Cong ammo". The article doesn't mention the author and gives two columns to the article. It highlights the word snooping by placing it in quotations. The headline calls out the revelation, explaining that the information handed out BJP a narrative against Congress.

Congress on Friday found itself battling the charge that former PM Jawaharlal Nehru subjected the relatives of Netaji Subhash Chandra Bose to intense surveillance for over two decades. (Times of India, 11.04.2015)

The publication is quick to point out that Nehru's surveillance of Bose's family could only amplify political brouhaha. The lead of the article frames Congress as the one "battling" to defend the disclosure. It positions Bose's family as a victim, clads and overemphasizes the rhetoric of the relatives being "subjected to" "intense surveillance", "over two decades". It is imperative to note here the subtle difference in treatment by the publication towards the political actors. While the honorific 'Netaji' given to Bose is retained, the 'Pandit' before Nehru is effectively absent.

On the same day, the article on Page 12, read "Subhash Chandra Bose's kin shocked" by "snoop gate". Like the previous article, the word 'shocked' is highlighted by placing it in a quotation, four of eight columns are given to the article, and it read:

BJP saw the disclosure through the prism of the legendary rivalry between Nehru and Bose. Nehru prevailed, largely because Mahatma Gandhi tipped the scales in his favor setting him on the path to becoming the first PM. Bose walked out of Congress but captured national imagination by seeking to liberate the country through an armed struggle. Netaji was feared killed after the aircraft carrying him crashed over Farmosa (now Taiwan) in 1945, but the legend about his heroic enterprise endure, leading many to passionately believe that he had survived the crash and would resurface to take charge of the country. (Times of India, 11.04.2015) 
The author adds the suffix 'gate' in the headline (an analogy to the Watergate) and hints at a far-reaching scam or scandal. The number of words in the lead is higher than the average. The publication adapts the position to rephrase history by placing BJP in charge of the narrative. Although the opinioned article is camouflaged, the thoughts reflected would hint at political conflict. The language fodders mythology and dramatization.

The author begins the article by labeling the Nehru-Bose equation as "legendary rivalry". A closer look at history may allow disputation of the assertion.

Times of India furthers the argument by disregarding Nehru's merit, popularity and achievements by largely crediting Gandhi's nominating Nehru to the position of India's first Prime Minister. The article also demolishes their stature by choice of phrases such as "Nehru prevailed", "Gandhi tipped the scale". Subsequently, a more heroic sketch of Bose has been penned. The author writes, "Bose walked out of Congress but captured national imagination by seeking to liberate the country through an armed struggle". The author's oversimplification of the antiquity becomes cautionary at this juncture as Bose resigned after twelve of fifteen Congress Working Committee members resigned on account of his conflict with Mahatma Gandhi, Congress's oldguard and with whom he had fallen out of favor since his contesting and winning the Congress Presidential Elections, defeating the Mahatma's candidate against his wishes.

The article is then incoherent in its tonality and shifts the narrative to mythology, platforms Bose as a "legend", and positions his endeavor to liberate India from the hands of the imperialist government as a "heroic enterprise". The author arrays reactionary notes to Bose's plane crash. Use of words "feared killed", "passionately believe", "resurface", "take charge" such words decorate the article in theatrical authorship. The author's stated mention of Bose's death/disappearance mystery is clad in folklore, instead of cognitive alternative argument which could state that a section of the public disregarded the announcement made by the Japanese News Agency on the $23^{\text {rd }}$ of August 1945 of a plane carrying Bose, crashing in Formosa due to lack of evidence. Many questioned the theory and no government in India since has accepted the mortal remains, fearing outrage from those quarters that do not believe in the crash theory.

The Statesman, on the same day, 11.04.2015, headlined their article, "Netaji 'snooping' triggers political storm". The publication too quotes the word "snooping". The lead of the article takes a similar political stand to Times of India but legitimizes their position by drawing conclusions from the fact that the interpretation drawn of Nehru's surveillance on Bose's relatives between 1948-68 was based out of the files declassified by the Intelligence Bureau.

The Statesman summarizes Congress's working over the years as "shockingly dubious track record". The publication masks it in a quotation, eliminating their years of working and leaving room to interpret if the quotation is the opinion of the publication or that of the BJP's. The next day, 12.04.2019, on Page 4, giving three columns, The Statesman, without mentioning the author, headline's, "Netaji was victim of conspiracy of Nehru and Congress: AIFB".

(...) All-India Forward Bloc today said that the nation must rise as one unit to establish the truth about the iconic leader "and completely expose the conspirator like Nehru. (The Statesman, 12.04.2019)

On May $3^{\text {rd }}$, 1939, Subhas Bose announced in Calcutta the formation of a new group within the Congress and named it the 'Forward Bloc'. He called out to all radicals to join the party after resigning from AICC. The lead of the article promotes nationalistic ideology by the actor in the text declaring, "the nation must rise as one unit". The article frames Nehru followed by the Congress as an antagonist in the whole narrative by positioning them as a "conspirator", whereas 
Bose being the "iconic leader". The author adds verbose such as "condemning", "imposing", "20 years", "truth", "expose", and "conspirator" to critique the actions of Nehru.

The second article published on the same day headlines, "Spying on Netaji's family: Naidu favors probe", The Statesman's article speaks of the approving position taken by a member of Bharatiya Janta Party, the force that stands to only gain from an investigation on the surveillance. The article takes a similar position in its rhetoric to emphasize on the catastrophic betrayal by Nehru.

Times of India, does not publish an article on the same day as The Statesman. The day after i.e. on 13.04.2015, Nauzer Bharucha authors a Page 1 article, headlines it "Our Worli home was watched, phone tapped: Bose's nephew". A reading of the lead does not elaborate on the surveillance, but frames Subhas Bose's nephew as a model of a brand, a business mogul's son, whose career started out as a hoax. It reads:

He had taken up the modeling assignment on a lark just because Maureen Wadia wanted him to (Times of India, 13.04.2015)

The author belittles the stature of the narrator and consequently his claims. Times of India, publishes another story on the same day, on Page 4, four of eight columns were given to the article, headlined "Plane crash was a fib: Bose's nephew",

Ardhendu believes there was no plane crash on August 18, 1945. "It was a fib. Nehru, Stalin, Mountbatten and the Congress Party never wanted him back as a hero because he was the most popular man in India, a man of destiny. (Times of India, 13.04.2015)

The actor in the lead is Ardhendu Bose, Bose's nephew, whose thoughts are established. The actor raises doubts on the plane crash of 1945, and critiques Nehru's surveillance over Bose's family. The quote by Ardhendu Bose ushers a framing of Bose as a threat for Nehru, Stalin, Mountbatten and Congress and hints at a global conspiracy for his disappearance. The language of the article is populated with grandiloquence, "hero", and "most popular man", "man of destiny". The Statesman, on the same day, presents Congress's point of view. On Page 1, the article headlines "Reports of snooping on Bose's kin are news plants: Congress",

Congress today accused the BJP and Narendra Modi government of running a "sinister campaign" against national icons as it dubbed reports of snooping on the family of Netaji Subhash Chandra Bose as motivated news plants based on selective leaks. (The Statesman 13.05.2015).

The article gives adequate locus to infiltrate doubts on the expose, summarizing it as politically motivated and debated disclosure. There is a discord in the direction adopted by the newspaper as the announcement of declassification on Bose files kept with the West Bengal government viz public plea that sustained for decades and could qualify as a historical move only features on Page 5 of the newspaper. The headline confirms the intent, it reads, "WB govt to dissect secret files of Netaji after polls", while the lead leaves doubt, it reads, "The state government will explore the possibility of declassifying files(...)". The article also swings between a possibility and an affirmation. A month later, West Bengal CM Mamata Banerjee declassified the files.

While Times of India exhausted its debate on Subhas Chandra Bose, The Statesman has been discreet, almost to the level of denying holistic information to its reader. All the articles 
clearly exalt political vendetta behind keeping the legend of Bose relevant. Articles have Nehru as the "actor" (Carvalho, 2005,2008) dominating the press narratives. The framing is not to levy justness towards Bose, but to diminish Nehru. It is imperative to note here that not a single article explores Bose as a solitary entity, who has been kept alive for political gains and favorable association.

\title{
4. Conclusion
}

\author{
"The media want to maintain their intimate relation to state power. They want to rub \\ shoulders with the Secretary of State, all that kind of business. To do that, you've got to play \\ the game, and playing the game means telling their lies, serving as their disinformation \\ apparatus"- Noam Chomsky
}

In 1997, a total of 990 files were declassified by the then United Front government lead by PM Inder Kumar Gujral. These files till date are kept at the National Archives of India. On $27^{\text {th }}$ August 1997 Times of India published just one article with the headline "Declassification of files will throw Netaji into spotlight"on Page 7 of its newspaper and the lead read:

More light on the circumstances surrounding the death of Netaji Subhas Chandra Bose, and also activities, and also of his Indian National Army (INA), will be shed next Tuesday when the defense minister declassifies and hands over 990 folders and files pertaining to the India to the INA to the National Archives of India. (27/08.1997)

Even in 1997, The Statesman did not acknowledge the news. The inexistence of Bose articles in an important national daily raises ethical concerns and allows deliberation on the partisan press of the country. The convenient overlooking of the 1997 declassification, no mentioning of its findings in any of the articles published in 2015, and the maneuvering of the present government's move as 'historical', reminds of ways we have failed to democratize the press and subsequently Bose.

The disqualifying opinions and inadequate locus in the 2015 articles, belies the freedom and objectivity of the press of the country. The vocabularies used by both newspapers are skewed, unceremonious and theatrical, rejecting journalistic discourse of fairness, non-partisan and well corroborated reportage. The authors manipulate realities to honor the present political frontrunners. A hyper- nationalistic viewpoint influences the texts. The Statesman's exclusion of information and contention of direction arises from affiliation to its political bequest. On the other hand, Times of India's passionate advancements legitimizes a favorable construction for the present political dynamics. It would appear from the sequence of events that having been left out for longest duration of time from the predominant discourse on the history of the freedom movement, the personality of Bose as an alternative to the hegemony of Gandhi and Nehru, is a major political conquest for the ruling party. In this politics of a subservient press, Subhas Bose remains a “...convenient prop" (Gordon, 1990).

\section{End Notes}

${ }^{1}<$ http://www.netajipapers.gov.in> (accessed on $10^{\text {th }}$ May 2019)

${ }^{2}$ With reference to archival research conducted on the articles published in Times of Indian and Statesman, it has been concluded that 2015 has the highest number of articles on Bose. 
${ }^{3}$ In the author's referenced year of study the paper was known as 'Statesman'.

${ }^{4}$ a sub-heading in an article, placed below the main headline

${ }^{5}$ Continuation of a story from one page to another

\section{References}

Bose, S. (2013). His Majesty’s Opponent: Subhas Chandra Bose and India's Struggle against Empire. Penguin UK.

Bhardwaj, Dr. R. C. (1994). Netaji and The INA. LokSabha Secretariat.

Carvalho, A. (2008). MEDIA(TED) DISCOURSE AND SOCIETY: Rethinking the framework of Critical Discourse Analysis. Journalism Studies, 9(2), 161-177. https://doi.org/10.1080/14616700701848162

Carvalho, A. (n.d.). Discourse Analysis and Media Texts: a Critical Reading of Analytical Tools! Centro de Estudos de Comunicacao e Sociedade.

Chakraborty, B. (1990). Subhas Chandra Bose and Middle Class Radicalism: A Study in Indian Nationalism 1928-1940. I.B. Tauris.

Chomsky, N. (n.d.).Language and Politics. A.K Press.

Dijk, T. A. V. (n.d.). 18 Critical Discourse Analysis.

Dijk, V. (1988).News As Discourse. Lawrence Erlbaun Associates, Publishers.

Edwardes, M. (1963). The Last Years of British India.

Fairclough, N. (n.d.). Discourse as Data: A guide for analysis edited by Margaret Wetherell, Stephanie Taylor, Simeon J Yates. In Discourse as Data: A guide for analysis edited by Margaret Wetherell, Stephanie Taylor, Simeon J Yates (p. 229)

Gordon, L. A. (1990). Brothers Against The Raj, A Biography of Indian Nationalist.

Happer, C., \& Philo, G. (2013).The role of the media in the construction of public belief and social change.Journal of Social and Political Psychology, 1 pp. 321-336.

Hasim, M. S., \&Tiung, L. K. (2009, September). (PDF) Media Framing of A Political Personality: A Case Study of a Malaysian Politician. Retrieved March 25, 2019, from ResearchGate websiteooo: https://www.researchgate.net/publication/235943880_Media_Framing_of_A_Political_Personality_ A_Case_Study_of_a_Malaysian_Politician

Haskins, J. B. (1966). Headline-and-Lead Scanning vs. Whole-Item Reading in Newspaper Content Analysis.Journalism Quarterly, 43(2), 333-335. https://doi.org/10.1177/107769906604300219

Hirschmann, E. (2004). The Hidden Roots of a Great Newspaper: Calcutta's “Statesman.” Victorian Periodicals Review, 37(2), 141-16o. Retrieved from JSTOR.

Jain, G. C. (1946). On To Delhi.

Jog, Frank, Werth, Saito, \&Hayashido. (n.d.).A Beacon Across Asia (1973). Orient Blackswan.

Mookerjee, N. (1981).Subhas Chandra Bose: The British press, Intelligence and Parliament.

Mani, A., \&Ramasamy, P. (2006, August). Subhas Chandra Bose and the Indian National Army: A Southeast Asian Perspective. In unpublished paper presented at the Seminar on "Forgotten Army in a World War: Subhas Bose's INA and Asia's Independence.

Postigo, M. L., Todoli, J., \&Dolón, R. (2006). 2006.What is critical discourse analysis? Quaderns de Filologia. EstudisLinguistics, Vol. XI. Retrievedfrom 
https://www.academia.edu/11590321/2006.What_is_critical_discourse_analysis

Richardson, J. (2006). Analysing Newspapers: An Approach from Critical Discourse Analysis. Macmillan Education UK.

Sathyamurthy, T. V. (1997). Indian Nationalism: State of the Debate. Economic and Political Weekly, 32(14), 715-721. Retrieved from JSTOR.

Shoemaker, P. J., \& Reese, S. D. (1996). Mediating the message: theories of influences on mass media content (2nd ed). White Plains, N.Y: Longman.

Taiwo, R. (2007). Language, Ideology and Power Relations in Nigerian Newspaper Headlines. 28.

Thomson, S. (2018). Differing Opinions: A Critical Discourse Analysis of Two Articles. University of Birmingham.

Vanderwicken, P. (1995, May 1). Why the News Is Not the Truth. Harvard Business Review, (May-June 1995). Retrieved from https://hbr.org/1995/05/why-the-news-is-not-the-truth

Wodak, R., \& Busch, B. (2004). Approaches to Media Texts.InThe SAGE Handbook of Media Studies (pp. 105122). https://doi.org/10.4135/9781412976077.n6

Wodak, R., \& Meyer, M. (2001). Methods of Critical Discourse Analysis. SAGE Publications, Inc. 